\title{
Molecular phylogeny and historical biogeography of the Aphanius (Pisces, Cyprinodontiformes) species complex of central Anatolia, Turkey
}

\author{
Tomas Hrbek, ${ }^{\mathrm{a}, *}$ Fahrettin Küçük, ${ }^{\mathrm{b}}$ Tancred Frickey, ${ }^{\mathrm{c}}$ Kai N. Stölting, ${ }^{\mathrm{a}}$ \\ Rudolph H. Wildekamp, ${ }^{\mathrm{d}}$ and Axel Meyer ${ }^{\mathrm{a}}$ \\ a Department of Biology, University of Konstanz, Konstanz 78457, Germany \\ b Süleyman Demirel University, Eğirdir Su Ürünlerl Fakültesi, Eğirdir 32500, Turkey \\ ${ }^{\mathrm{c}}$ Max Plank Institut Entwicklungsbiologie, Abt I, Tuebingen 72076, Germany \\ ${ }^{\mathrm{d}}$ Royal Museum of Central Africa, Vertebrate Section, Tervuren 3080, Belgium
}

Received 2 August 2001; received in revised form 28 January 2002

\begin{abstract}
Phylogenetic relationships of a subset of Aphanius fish comprising central Anatolia, Turkey, are investigated to test the hypothesis of geographic speciation driven by early Pliocene orogenic events in spite of morphological similarity. We use 3434 aligned base pairs of mitochondrial DNA from 42 samples representing 36 populations of three species and six outgroup species to test this hypothesis. Genes analyzed include those encoding the $12 \mathrm{~S}$ and $16 \mathrm{~S}$ ribosomal RNAs; transfer RNAs coding for valine, leucine, isoleucine, glutamine, methionine, tryptophan, alanine, asparagine, cysteine, and tyrosine; and complete NADH dehydrogenase subunits I and II. Distance based minimum evolution and maximum-likelihood analyses identify six well-supported clades consisting of Aphanius danfordii, Aphanius sp. aff danfordii, and four clades of Aphanius anatoliae. Parsimony analysis results in 462 equally parsimonious trees, all of which contain the six well supported clades identified in the other analyses. Our phylogenetic results are supported by hybridization studies (Villwock, 1964), and by the geological history of Anatolia. Phylogenetic relationships among the six clades are only weakly supported, however, and differ among analytical methods. We therefore test and subsequently reject the hypothesis of simultaneous diversification among the six central Anatolian clades. However, our analyses do not identify any internodes that are significantly better supported than expected by chance alone. Therefore, although bifurcating branching order is hypothesized to underlie this radiation, the exact branching order is difficult to estimate with confidence.
\end{abstract}

Keywords: Aphanius sp. complex; Anatolia; Turkey; Biogeography; Tethys; Speciation; Molecular phylogeny; Rapid diversification

\section{Introduction}

Allopatric speciation is the primary mode of speciation in nature (Futuyma and Mayer, 1980; Mayr, 1942). Geographic speciation whereby a population gets divided into two or more populations as a result of a formation of a geographic barrier that prevents among population gene flow, and these populations subsequently diverge sufficiently to become distinct species, is viewed as the most common form of allopatric specia-

\footnotetext{
${ }^{*}$ Corresponding author. Fax: +49-7531-883018.

E-mail address: tomas.hrbek@uni-konstanz.de (T. Hrbek).
}

tion (Futuyma and Mayer, 1980). Geologically active regions within which many geographically isolated regions lie should therefore be ideal candidates for testing the geographic speciation hypothesis. The Mediterranean region as well as Turkey and Iran lie within a geologically very active area resulting from the northward movement of the African plate and the resulting closing of the Tethys Sea (Sengör et al., 1988). In particular Anatolia, the Asiatic part of Turkey, is geologically complex, composed of six major tectonic units, five of which compose central Anatolia (Sengör and Yilmaz, 1981), and should therefore act as an agent of geographic speciation. This hypothesis has been investigated so far on a very limited geographic scale. 
Weisrock et al. (2001) investigated the geographic diversification of the Mertensiella luschani complex of salamanders within one of these tectonic units, the southwestern section of the Menderez-Taurus block of Turkey, finding up to 7 million year divergence among populations within this region. These results are well collaborated by the geological history of the southwestern section of the Menderez-Taurus block, which predicts 5-10 million year divergence (Waldron, 1984). However, to date no studies have tested the effects of the conglomeration of the six main geological blocks comprising present-day Anatolia on more widespread Anatolian fauna or flora. We therefore investigate the phylogenetic relationships and the timing of amongclade divergence events of the Aphanius anatoliae species complex of Anatolia.

The center of diversity of the killifish genus Aphanius (Order: Cyprinodontiformes) is in Turkey (Wildekamp et al., 1999). Of the 14 described species in the genus, six species and four subspecies comprising two major clades (Hrbek and Meyer, 2002) occur in Anatolia. Other species inhabit the greater Mediterranean realm, periphery of the Red Sea, the Arabian Sea, and the Persian Gulf, and inland basins of Iran. Within central Anatolia, three species occur (Fig. 1). The typical habitats of Aphanius in this region are springs, small creeks, and marshes. A. danfordii is present in the whole of the Kızılırmak and the lower Yeşilırmak River drainages and the Develi Depression (Fig. 1, Region I). Aphanius sp. aff. danfordii (Wildekamp et al., 1999) is found in the upper Sakarya River drainage and areas surrounding Lake Çavuşçu; the Haymana basin (Fig. 1, Region II). The third species, Aphanius anatoliae, has the widest distribution, shows the greatest morphological diversity, and lives in the largest range of habitat types. In the northwestern portion of its distribution, A. anatoliae is found in the Büyük-Menderez River drainage (Fig. 1, Region $\mathrm{V}$ ); in the eastern portion of its distribution, it is found in creeks and springs of the Tuzgölü basin (Fig. 1, Region III), while in the southwestern portion of its distribution, it is found predominantly in springs and marshes of small isolated inter-montane basins (Fig. 1, Regions IV and VI). The southwest region also contains large lakes inhabited by populations of $A$. anatoliae, some of which have evolved distinct limnetic phenotypes, i.e., fusiform phenotypes adapted to open-water environments (Fig. 1, Region IV). With the exception of the limnetic populations from Region IV, all other populations and species show remarkably little morphological differentiation within and among populations. The sister species to this clade is A. asquamatus, which occurs only in Lake Hazer, eastern Turkey (Hrbek and Meyer, 2002; Wildekamp et al., 1999). Distribution and sampling localities are shown in Fig. 1.

Villwock (1964) was the first to conduct a comprehensive study of the relationships of Anatolian members of the genus Aphanius by means of hybridization, building upon earlier taxonomic and systematic studies of Kosswig (1953, 1956). Hybridization experiments with endemic Anatolian populations resulted in the division of the populations into three groups named Kizılırmak, central Anatolian, and southwest Anatolian (Villwock, 1964). The Kizilırmak group was reproductively isolated from the central Anatolian and southwest Anatolian groups; the central Anatolian and the southwest Anatolian groups showed partial reproductive isolation. Villwock (1964) concluded that the Kizılırmak River group represented a distinct and valid species $A$. chantrei, later synonymized with $A$. danfordii by Wildekamp et al. (1999). Both the central and southwest Anatolian groups were placed into A. anatoliae, in spite of showing partial reproductive isolation. Villwock (1964) also investigated the relationships of the Lake Çavuşçu population (called Ilgın population in Villwock, 1964) to other Aphanius populations. In spite of being reproductively isolated from all other populations, the only exception being Ilgin $\times$ Obruk cross that resulted in F2 larval mortality, the Lake Çavuşçu fish were included in $A$. anatoliae. The assignment of the Lake Çavuşçu fish to $A$. anatoliae was conservative, since no other related populations were available for comparison at the time of Villwock's (1964) study. However, based on recent collections, additional populations of this group are known from numerous areas of the upper Sakarya River drainage system, suggesting that this group is likely to represent another reproductively isolated lineage.

Based on Villwock's (1964) studies, it appears that central Anatolia is inhabited by at least four reproductively isolated groups, which occupy distinct geological units (Sengör and Yilmaz, 1981), but are morphologically very similar. The study of relationships among the three central Anatolian species and their populations therefore provides an excellent opportunity for investigating historical biogeography of the Anatolian region. To test the role of Anatolian geologic events as agents of diversification, we analyze mitochondrial DNA data of 36 central Anatolian Aphanius populations, including all known species and relevant geographic regions in which these populations occur (Fig. 1).

\section{Materials and methods}

\subsection{Selection of outgroup and ingroup taxa}

To investigate phylogenetic relationships among the central Anatolian species of Aphanius, we chose all known species represented by 36 populations ( $A$. anatoliae -27 populations; $A$. sp. aff. danfordii-5 populations; and $A$. danfordii-4 populations) spanning all known geographic regions of occurrence. We chose the sister group Aphanius 


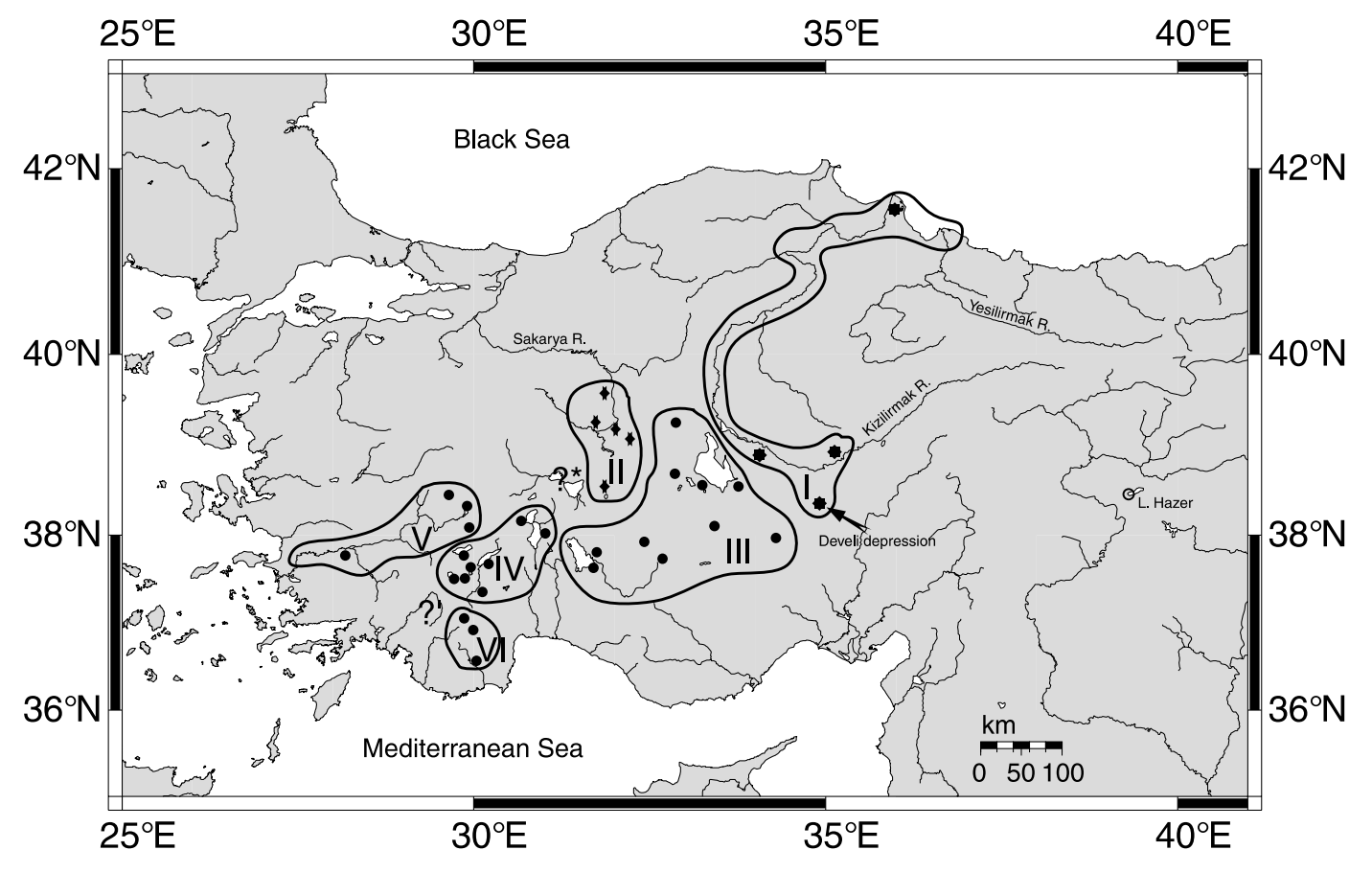

- Aphanius anatoliae clades III, IV, V, VI

Aphanius danfordii
clade I
- Aphanius sp. aff. danfordii clade II
- Aphanius asquamatus

Fig. 1. Distribution area of the killifishes of the genus Aphanius. Localities included in this study are marked by species specific symbols. Roman numerals correspond to: I_Kizilirmak drainage clade/region; II-Haymana basin clade/region; III_-Tuzgölü basin clade/region; IV_Lakes District clade/region; V-Büyük-Menderez drainage clade/region; and VI-Southwestern clade/region. The ?* corresponds to the internal basin of Lakes Eber and Akşehir and ?' to Lake Gölhisar of the Dalaman River basin whose Aphanius populations have recently gone extinct, but may have represented distinct clades. Region I is part of the Kirşehir block; regions IV and VI are part of the Taurus-Menderez block; region II lies at the periphery of the Sakarya continent; region III forms an internal basin between the Kirşehir block, the Taurus-Menderez block, and the Sakarya continent; and region $\mathrm{V}$ lies at the junction of the Taurus-Menderez block and the Sakarya continent (see Fig. 5). Region II contains Lake Çavuşçu, southern most locality; region III contains Lake Beyşehir drained by River Çarşamba, eastern most lake; and region IV contains Lakes Eğirdir, Burdur, Yarişli, Aci, and Salda from east to west, respectively.

asquamatus from Lake Hazer, eastern Turkey, and more distantly related species including Aphanius fasciatus (from Adana, Turkey), Aphanius sophiae (from Shiraz, Iran), Aphanius vladykovi (from Boldaji, Iran), Aphanius iberus (from Santa Pola, Spain), and A. apodus (from Aïn M'Lila, Algeria) as outgroups. The chosen outgroups represent the closest outgroups from the western clade of Aphanius (Hrbek and Meyer, 2002). Table 1 lists species and populations used in the study, as well as the GenBank accession numbers.

\subsection{Laboratory protocols}

Total genomic DNA was extracted from muscle tissue of the right caudal peduncle of specimens preserved in 95\% ethanol. Muscle tissue was dissolved and digested with a proteinase K/SDS solution, followed by phenol and chloroform extraction, the addition of $5 \mathrm{M} \mathrm{NaCl}$ followed by $70 \%$ ethanol precipitation of DNA product.

Polymerase chain reaction (PCR) amplification was performed on total genomic DNA. Negative controls were performed for all reactions. The temperature pro- file for the 30-cycle amplification reaction consisted of denaturation at $94^{\circ} \mathrm{C}$ for $35 \mathrm{~s}$, annealing at $50^{\circ} \mathrm{C}$ for $35 \mathrm{~s}$, and extension at $72^{\circ} \mathrm{C}$ for $90 \mathrm{~s}$ per cycle. The resulting products were evaluated on a $1 \%$ agarose gel and then purified with Qiagen spin-columns. Amplified mtDNA segments were sequenced from both the $5^{\prime}$ and $3^{\prime}$ ends. Sequencing reactions followed standard PerkinElmer Big Dye sequencing protocol for double-stranded cycle sequencing reactions. Sequences were determined on a Perkin-Elmer ABI 3100 automatic DNA sequencer. Amplification and sequencing primers were previously published in Hrbek and Meyer (2002). The mtDNA region analyzed includes the $3^{\prime}$ half of the $12 \mathrm{~S}$ rRNA, the tRNA ${ }^{\mathrm{Val}}$, and the $5^{\prime}$ end of the 16S rRNA; a second contiguous segment consists of the $3^{\prime}$ end of the $16 \mathrm{~S}$ rRNA, tRNA ${ }^{\mathrm{Leu}}$, the genes encoding the NADH dehydrogenase subunit 1, tRNA ${ }^{\text {Ile }}$, tRNA ${ }^{\text {Gln }}$, tRNA ${ }^{\text {Met }}$, NADH dehydrogenase subunit 2 , tRNA ${ }^{\text {Trp }}$, tRNA ${ }^{\text {Ala }}$, tRNA $^{\text {Cys }}$, tRNA ${ }^{\text {Tyr }}$, the $3^{\prime}$ end of the subunit 1 of cytochrome $c$ oxidase, and including the replication origin for the light strand $\left(\mathrm{O}_{\mathrm{L}}\right)$ between the tRNA ${ }^{\text {Asn }}$ and tRNA ${ }^{\text {Cys }}$ genes. At least two individuals per population 
Table 1

Species and localities included in this study

\begin{tabular}{|c|c|c|c|}
\hline Species & Population & Clade & GenBank Accession Nos. \\
\hline Aphanius anatoliae splendens & Lake Salda & IV & AF451623, AF451659 \\
\hline Aphanius anatoliae sureyanus & Lake Burdur & IV & AF451624, AF451660 \\
\hline Aphanius anatoliae transgrediens (1) & Lake Aci (spring 1) & IV & AF451625, AF451661 \\
\hline Aphanius anatoliae transgrediens (2) & Lake Aci (spring 5) & IV & AF451626, AF451662 \\
\hline Aphanius anatoliae transgrediens (3) & Lake Aci (spring 6) & IV & AF451627, AF451663 \\
\hline Aphanius anatoliae anatoliae (1) & Pínarbaşí near Kemer & IV & AF451628, AF451664 \\
\hline Aphanius anatoliae anatoliae (2) & Düğer near Burdur & IV & AF451629, AF451665 \\
\hline Aphanius anatoliae anatoliae (3) & Karapínar near Yeşilova & IV & AF451630, AF451666 \\
\hline Aphanius anatoliae anatoliae (4) & Lake Eğirdir at Karaot & IV & AF451631, AF451667 \\
\hline Aphanius anatoliae anatoliae (5) & Lake Eğirdir at Akkeçili & IV & AF451632, AF451668 \\
\hline Aphanius anatoliae anatoliae (6) & Eumeneia springs near Isıklı & V & AF451633, AF451669 \\
\hline Aphanius anatoliae anatoliae (7) & Lake Isıklı near Beydilli & $\mathrm{V}$ & AF451634, AF451670 \\
\hline Aphanius anatoliae anatoliae (8) & Akçay near Nazilli & $\mathrm{V}$ & AF451635, AF451671 \\
\hline Aphanius anatoliae anatoliae (9) & Karakuyu wetland near Dinar & V & AF451636, AF451672 \\
\hline Aphanius anatoliae anatoliae (10) & Güneşli near Eşmekaya & III & AF451637, AF451673 \\
\hline Aphanius anatoliae anatoliae (11) & Insuyuköyü near Cihanbeyli & III & AF451638, AF451674 \\
\hline Aphanius anatoliae anatoliae (12) & Baltalin near Kulu & III & AF451639, AF451675 \\
\hline Aphanius anatoliae anatoliae (13) & Göyazı near Cihanbeyli & III & AF451640, AF451676 \\
\hline Aphanius anatoliae anatoliae (14) & Yenikent near Aksaray & III & AF451641, AF451677 \\
\hline Aphanius anatoliae anatoliae (15) & Eflatun Pínarí near Beyşehir & III & AF451642, AF451678 \\
\hline Aphanius anatoliae anatoliae (16) & Thaliye Canal near Sulamasi & III & AF451643, AF451679 \\
\hline Aphanius anatoliae anatoliae (17) & Lake Beyşehir at Beyşehir & III & AF451644, AF451680 \\
\hline Aphanius anatoliae anatoliae (18) & Erler near Konya & III & AF451645, AF451681 \\
\hline Aphanius anatoliae anatoliae (19) & Akkaya dam near Niğde & III & AF451646, AF451682 \\
\hline Aphanius anatoliae anatoliae (20) & Lake Avlan near Elmalı & VI & AF451647, AF451683 \\
\hline Aphanius anatoliae anatoliae (21) & Kırkpınar near Kortuteli & VI & AF451648, AF451684 \\
\hline Aphanius anatoliae anatoliae (22) & Sögüt near Kortuteli & VI & AF451649, AF451685 \\
\hline Aphanius sp. aff. danfordii (1) & Imamoglu creek near Hacıfakılı & II & AF451650, AF451686 \\
\hline Aphanius sp. aff. danfordii (2) & Lake Çavuşçu & II & AF451651, AF451687 \\
\hline Aphanius sp. aff. danfordii (3) & Küçükhasan near Çeltik & II & AF451652, AF451688 \\
\hline Aphanius sp. aff. danfordii (4) & Pínarbaşí near Çeltik & II & AF451653, AF451689 \\
\hline Aphanius sp. aff. danfordii (5) & Salihler near Emirdağ & II & AF451654, AF451690 \\
\hline Aphanius danfordii (1) & Soysali by Sultan Swamps & I & AF451655, AF451691 \\
\hline Aphanius danfordii (2) & Kizılırmak River delta & I & AF451656, AF451692 \\
\hline Aphanius danfordii (3) & Gözler by Kirşehir & I & AF451657, AF451693 \\
\hline Aphanius danfordii (4) & Karpuzatan by Kayseri & I & AF451658, AF451694 \\
\hline Aphanius asquamatus & Lake Hazer, Turkey & & AF449306, AF449368 \\
\hline Aphanius fasciatus & Lake Bafa, Turkey & & AF449310, AF449372 \\
\hline Aphanius sophiae & Lake Maharloo near Shiraz, Iran & & AF449314, AF449376 \\
\hline Aphanius vladydovi & Boldaji basin, Iran & & AF449315, AF449377 \\
\hline Aphanius iberus & Santa Pola, Spain & & AF449317, AF449379 \\
\hline Aphanius apodus & Aïn M'Lila, Algeria & & AF449323, AF449385 \\
\hline
\end{tabular}

All ingroup species and populations are from Turkey. GenBank accession numbers are listed for the 12S, and then the ND1 and ND2 fragments, respectively.

were completely sequenced to assure that individuals were representative of their populations; however, only one randomly selected individual was used in analyses, since individuals were identical or differed by only a few base pairs.

\subsection{Data analysis}

Homologous protein-coding regions (ND1, ND2) were aligned manually and confirmed by translating DNA data into amino acid sequences in BioEdit (Hall, 1999). Alignments of ribosomal and transfer RNAs were constructed manually based on secondary structural models (Kumazawa and Nishida, 1993; Ortí and Meyer,
1997; Ortí et al., 1996). A total of 3434 alignable characters representing 36 populations of three ingroup and six outgroup taxa were scored; 1262 of these characters were variable and 933 were parsimony informative. Total sequence length ranged from 3443 to 3451 characters. We excluded the loop of the d-arm of the tRNA ${ }^{\text {Cys }}$ and the loop of light-strand replication origin, since these regions were unalignable. All sequences were tested for an anti-G bias characteristic of the mitochondrial DNA genes, to confirm that we have collected genuine mitochondrial DNA data (Zhang and Hewitt, 1996). All sequence data have been deposited in GenBank (Table 1). A file with the aligned data is available directly from the first author at www.cyprinodontiformes.org. 
Maximum parsimony based phylogenetic relationships were estimated using the program PAUP* (Swofford, 2001) with 100 heuristic searches using random additions of sequences and implementing the tree bisection and reconnection (TBR) algorithm. Equal weight was given to all characters. Bootstrap resampling (Felsenstein, 1985a) was applied to assess support for individual nodes using 2000 bootstrap replicates with 10 random additions and TBR branch swapping.

Distance based minimum evolution phylogenetic relationships were estimated using the program TreeCon (Van de Peer and De Wachter, 1997). The Van de Peer and de Wachter model (Van de Peer et al., 1996) of molecular evolution was used, since it allows among site rate variation, and thus, is comparable to the HKY85 model (Hasegawa et al., 1985) with gamma distributed among site rate variation. Support for individual branches was estimated using 2000 bootstrap replicates.

Maximum likelihood based phylogenetic relationships were estimated using the program PAUP* (Swofford, 2001) and implementing a full heuristic search of the tree space. The HKY85 model (Hasegawa et al., 1985) of evolution with rate heterogeneity, rates for variable sites assumed to follow the gamma distribution with shape parameter estimated by the maximum-likelihood method was used to arrive at the topology with the highest likelihood.

\subsection{Test for hard vs. soft polytomy}

To evaluate whether a hard polytomy (simultaneous or nearly simultaneous branching from a common ancestral lineage) or a soft polytomy (successive branching of lineages that have relatively short internode length and thus are not well supported) exists in areas of the tree that have low branch support, we test the hypothesis that the best fully resolved tree is not significantly better supported than an unresolved phylogenetic tree (Kishino and Hasegawa, 1989; Templeton, 1983). We assume that lineages supported by bootstrap values of less than $70 \%$, nodes which have confidence intervals of less than 95\% (Hillis and Bull, 1993), are not supported with confidence. We collapse these nodes and test the resulting tree against the best fully resolved tree. Rejection of the null hypothesis of simultaneous branching will support the conclusion that short internode branch lengths represent a soft polytomy.

To investigate which internodes, if any, within the area of the soft polytomy are significantly better supported than expected by chance alone, we perform a randomization test to generate a null distribution of branch-support values (Bremer, 1994) and internode branch lengths against which we compare branch-support values (Bremer, 1994) and internode branch lengths computed from the best phylogenetic hypotheses (Felsenstein, 1985b; Jackman et al., 1999).
The assumption of this test is that we have a sufficient number of phylogenetically informative characters and the addition of more phylogenetically informative characters will not improve phylogenetic signal significantly (Graybeal, 1998; Hillis, 1996). Alternatively, we may need hundreds or thousands of additional informative characters to improve confidence in a particular node (Philippe et al., 1994); however, these data may be impractical or impossible to collect.

\section{Results}

\subsection{Phylogenetic relationships}

We conduct three separate sets of analyses. The data are analyzed using maximum parsimony, minimum evolution, and maximum likelihood. The resulting phylogenies are largely congruent. The only significant differences observed among the three methods of analysis are the phylogenetic relationships among the six clades consisting of $A$. danfordii, A. sp. aff. danfordii, and four clades of A. anatoliae (Figs. 24). The clades correspond to geographically well-defined areas. Aphanius danfordii (Fig. 1, Clade I; Fig. 2) inhabits the Kızılırmak and Yeşilırmak River drainages plus the Sultan swamps of the Develi depression, the southern most locality in Fig. 1, Clade I. The Develi depression is separated from the Kizılirmak River drainage by a volcanic mountain chain. Aphanius sp. aff. danfordii inhabits the Haymana basin, which includes the upper reaches of the Sakarya River as far south as Lake Çavuşçu (Fig. 1, Clade II; Fig. 2). The four remaining clades comprise $A$. anatoliae from the Tuzgölü basin (Fig. 1, Clade III; Fig. 2), from the Lakes District (Fig. 1, Clade IV; Fig. 2), from the Büyük-Menderez River drainage (Fig. 1, Clade V; Fig. 2), and from the Southwest (Fig. 1, Clade VI; Fig. 2). The monophyly of these six central Anatolian Aphanius clades is well supported in all analyses; however, the phylogenetic relationships among these six clades are not strongly resolved, the bootstrap values of all internodes being less than $70 \%$. Branch lengths among these six lineages are relatively short as well (Figs. 2 and 4).

The base pair composition (average $\mathrm{A}=0.263$, $\mathrm{C}=0.294, \mathrm{G}=0.174, \mathrm{~T}=0.269$ ) shows anti-G bias characteristic of mitochondrial genes but not of nuclear genes (Zhang and Hewitt, 1996). The data show no saturation, even in third positions of ND1 and ND2 genes. Uncorrected pairwise sequence divergence among the six major clades ranges from $7.4 \%$ to $9.2 \%$. Our data also contain large number of informative characters, both with the ingroup, and between the outgroup and the ingroup. The number of parsimony informative characters (933) was more than 22 times the number of 


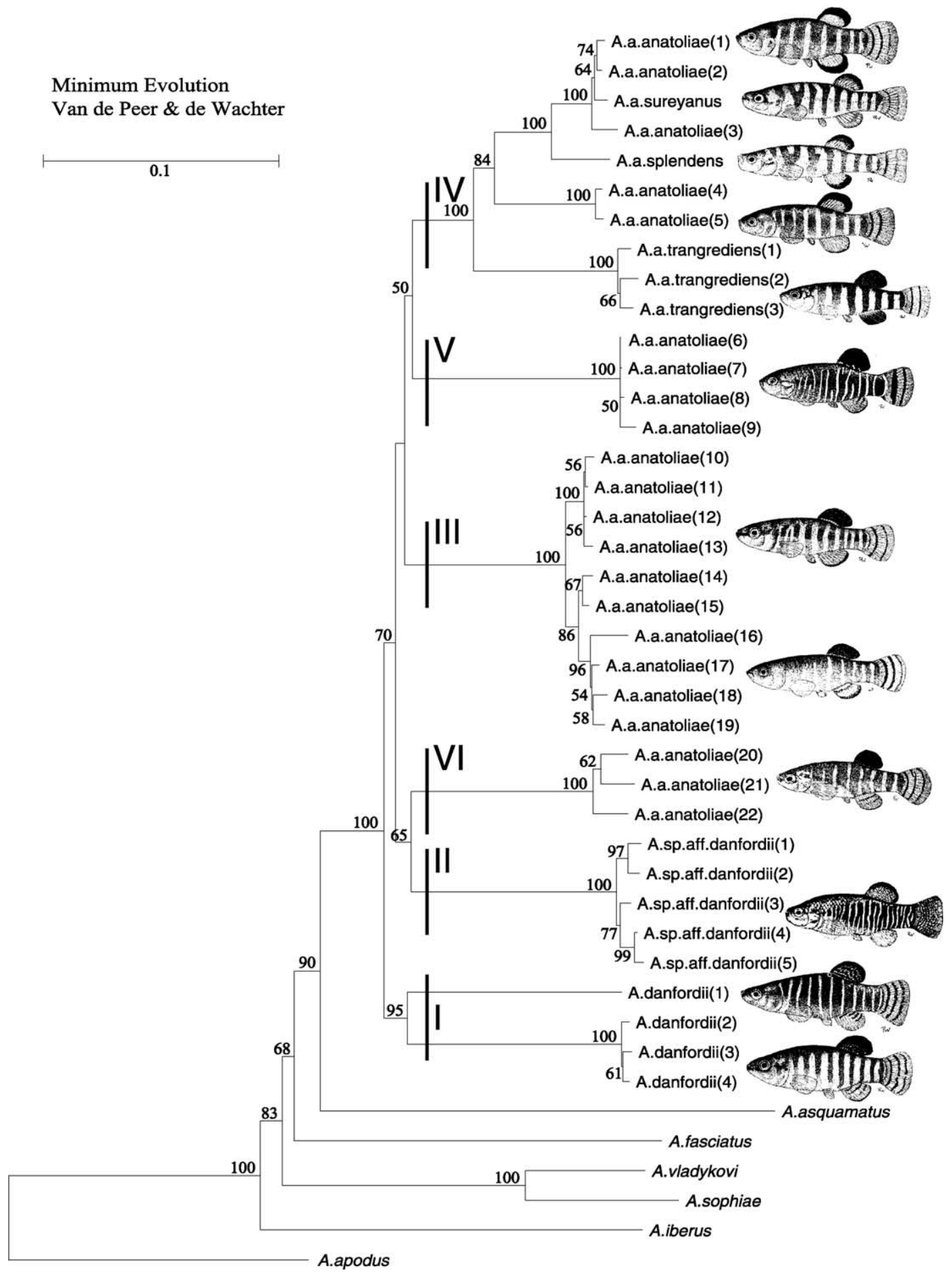

Fig. 2. Minimum evolution estimate of the phylogenetic relationships of the genus Aphanius; ME $=0.93343$. Values above branches indicate bootstrap values based on 2000 replicates. Numbers after specific names refer to geographic locations listed in Table 1 from which the specimens originate. Clade designations are indicated by labeled bars and correspond to clades in Fig. 1. Drawings portray representative members of given populations or species.

taxa (42) sampled. Of the 933 parsimony informative characters, the data contain 219 parsimony informative characters that span the internodes among the six main central Anatolian clades; thus, we have nearly 35 times as many characters as clades.

\subsection{Hard polytomy vs. soft polytomy}

To test whether the branching pattern among these six lineages supports the hypothesis of a hard polytomy, we compare the strict consensus of the most parsimo- 
Maximum Parsimony
Consensus of 464 trees

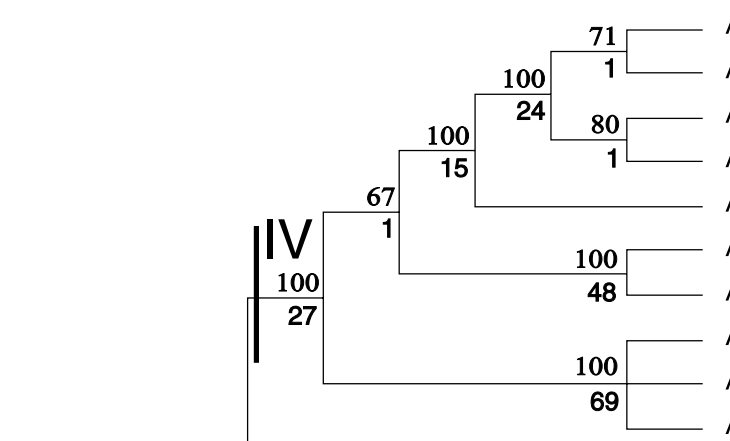

A.a.sureyanus

A.a.anatoliae(3)

A.a.anatoliae(1)

A.a.anatoliae(2)

A.a.splendens

A.a.anatoliae(4)

A.a.anatoliae(5)

A.a.trangrediens(3)

A.a.trangrediens(2)

A.a.trangrediens(1)

A.sp.aff.danfordii(5)

A.sp.aff.danfordii(4)

A.sp.aff.danfordii(3)

A.sp.aff.danfordii(2)

4 A.sp.aff.danfordii(1)

$2 \mid$ V $52 \square$ A.a.anatoliae(20)

A.a.anatoliae(22)

A.a.anatoliae(21)

A.a.anatoliae(9)

A.a.anatoliae(8)

A.a.anatoliae(7)

A.a.anatoliae(6)

A.a.anatoliae(19)

A.a.anatoliae(18)

A.a.anatoliae(17)

A.a.anatoliae(16)

A.a.anatoliae(15)

A.a.anatoliae(14)

A.a.anatoliae(13)

A.a.anatoliae(12)

A.a.anatoliae(11)

A.a.anatoliae(10)

A.danfordii(4)

A.danfordii(3)

A.danfordii(2)

A.danfordii(1)

A.asquamatus

A.vladykovi

A.sophiae

A.fasciatus

A.iberus

A.apodus

Fig. 3. Maximum parsimony estimate of the phylogenetic relationships of the genus Aphanius; $\mathrm{TL}=3411, \mathrm{CI}=0.529$. Values above branches indicate bootstrap values based on 2000 replicates. Values below branches refer to Bremer branch-support values. Numbers after specific names refer to geographic locations listed in Table 1 from which the said specimens originate.

nious phylogenetic trees with the same strict consensus of the most parsimonious phylogenetic trees where the phylogenetic relationship among the six Anatolian clades is left completely unresolved tree using the Wilcoxon signed-rank test (Templeton, 1983). We also compare the best phylogenetic hypotheses obtained under minimum evolution and maximum-likelihood criteria using the Kishino-Hasegawa test (Kishino and Hasegawa, 1989). Both the Wilcoxon signed-rank test as well as the Kishino-Hasegawa test reject the hypothesis of a hard polytomy (MP: Templeton test $z=9.79$, $p=0.0001$; ME: Kishino-Hasegawa test $t=11.98$, 
Maximum Likelihood

HKY $85+$ gamma + I
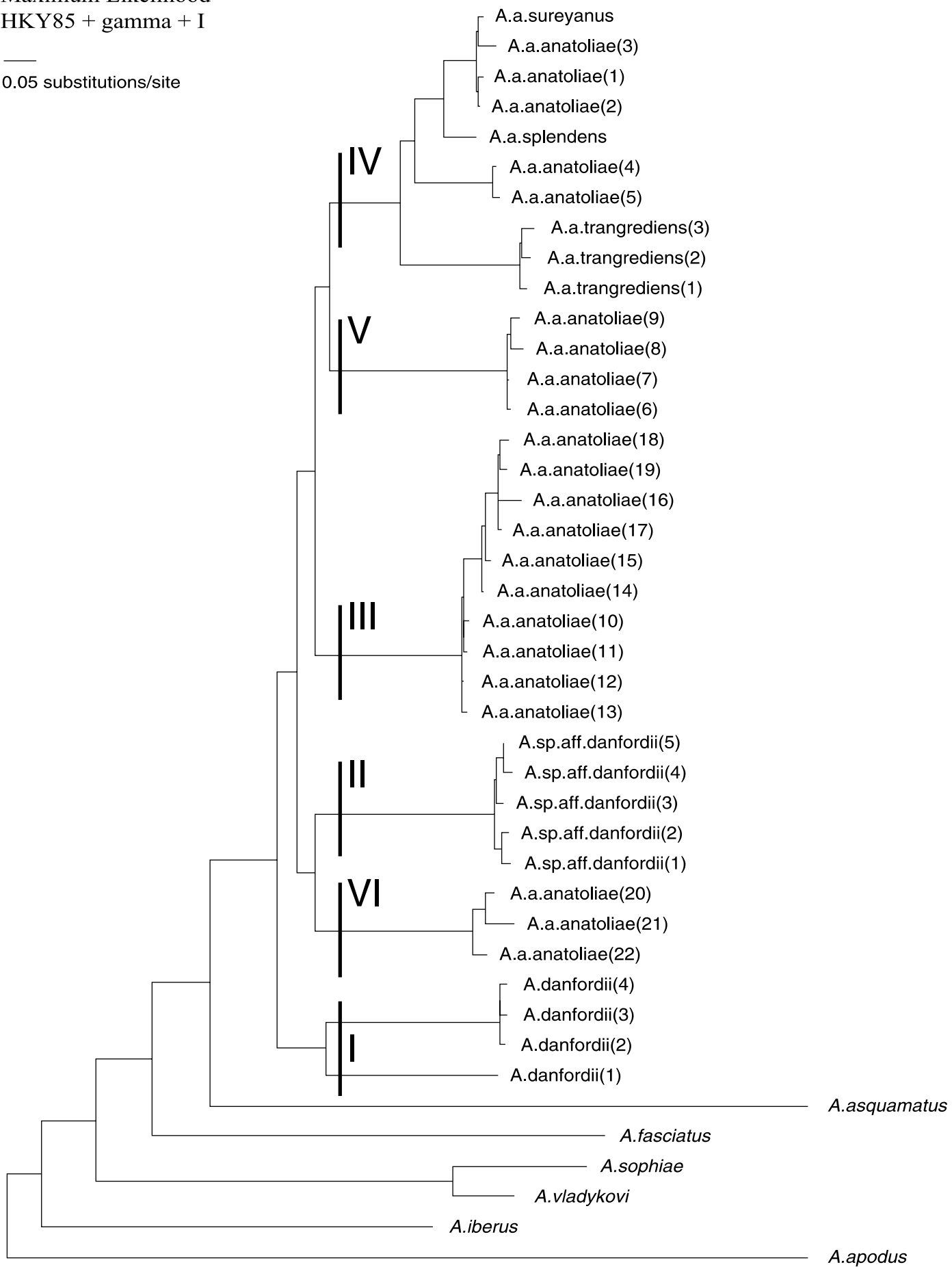

Fig. 4. Maximum-likelihood estimate of the phylogenetic relationships of the genus Aphanius based on TBR rearrangements of the best maximumlikelihood topology. For the HKY85 model, transition/transversion ratio was calculated at 3.733, the shape parameter alpha equals 0.701 , and the proportion of invariable sites is $0.464 ;-\ln =20319.303$. Numbers after specific names refer to geographic locations listed in Table 1 from which the said specimens originate.

$p<0.0001 ;$ ML: Kishino-Hasegawa test $t=10.53$, $p<0.0001)$. We therefore test which internodes, if any, within the area of the soft polytomy are significantly better supported than expected by chance alone.

We reduce the original data set into a subset containing one outgroup (A. asquamatus) and one randomly chosen taxon from each of the six central Anatolian Aphanius lineages, thus, creating a data set containing seven taxa. Based on this new subset, we generate 1000 random data sets by permuting the characters of the ingroup. We also simulate 1000 new data sets based on maximum-likelihood parameters obtained from the 
reduced data set assuming completely unresolved topology using the program Seq-Gen (Rambaut and Grassly, 1997). Phylogenetic relationships are estimated from the randomized and simulated data sets as above. The taxa of the resulting trees are subsampled to include the most nested three member clade and its most distant ingroup relative (Felsenstein, 1985b; Jackman et al., 1999). Metrics in the form of branch-support values (Bremer, 1994) and internode branch lengths are computed. Null distributions of the metrics are generated and metrics obtained from the original data set are compared to the null distribution; $95 \%$ cut-off, two-tailed tests are used. Specific tests conducted are as follows:

1. Maximum parsimony: We conduct a Bremer branch-support analysis (Bremer, 1994) of the randomized data set testing the null hypothesis of no significant difference in branch-support values between the randomized and the original data set. The $95 \%$ branchsupport value cut-off is 10 . None of the nodes in question show significantly better support than expected by chance alone based on this criterion.

2. Maximum parsimony, minimum evolution, and maximum likelihood: We conduct an internode branchlength analysis of both the randomized (MP and ME) and the simulated (ML) data sets, testing the null hypothesis of no significant difference in internode branchlengths between random and simulated data sets and the original data set. The $95 \%$ branch-length value cut-offs for the randomized and the simulated data sets are 59 and 62 steps, respectively. Based on this analysis, no branch is considered to be significantly better supported than expected by chance alone.

Based on our results, it appears that although central Anatolian Aphanius have undergone rapid diversification, the diversification was not simultaneous. The hypothesis of a simultaneous diversification is significantly less well supported than the best fully resolved phylogeny. However, none of the internodes spanning the diversification of the six main Anatolian clades are significantly better supported than expected by chance alone. Therefore, although sequential branching order is hypothesized to underlie this radiation, the correct estimation of the actual branching order is difficult to infer and may remain so even with the addition of more data (Philippe et al., 1994).

\section{Discussion}

\subsection{Molecular evolution of central Anatolian Aphanius species}

Six major lineages are identified within central Anatolian Aphanius. Subsampling using four-taxon combinations suggests that these six lineages diverged relatively rapidly in time, i.e., are of similar but not of identical age, since we reject the hypothesis of simultaneous or near simultaneous diversification of these six lineages. Uncorrected pairwise sequence divergence ranges from $7.4 \%$ to $9.2 \%$, suggesting a $11.5-14.1$ million year separation among clades. A substitution rate of $0.64 \%$ pairwise sequence divergence per million years is calibrated against the separation of $A$. sirhani from A. dispar (Hrbek and Meyer, 2002). The six areas of distribution, the southwestern block (Fig. 1, Region VI), the Lakes District (Fig. 1, Region IV), the BüyükMenderez River drainage (Fig. 1, Region V), the Tuzgölü basin (Fig. 1, Region III), the Haymana basin (Fig. 1, Region II), and the Kızılırmak and Yeşilırmak River drainages plus the Sultan swamps of the Develi depression (Fig. 1, Region I) are monophyletic and monophyly of the groups is well supported. No exchange of individuals among these areas is observed and haplotype sharing among populations within clades is not observed. The only clades that show appreciable levels of divergence are the Lakes District and the Kızllırmak River drainage clades. Maximal divergence within the Lakes District clade is estimated to be 7.1 million years ( $4.6 \%$ pairwise sequence divergence), while the divergence of the Develi depression Aphanius population from the Kizılırmak River drainage populations is estimated to be 12.3 million years $(7.9 \%$ pairwise sequence divergence). Relatively shallow divergence of populations in the Tuzgölü basin (1.3\%) and the BüyükMenderez $(0.1 \%)$, the Sakarya $(1.0 \%)$, and the Kizılırmak $(0.4 \%)$ River drainages suggests a much more recent isolation of populations.

The degree of intraspecific differentiation observed among lineages of $A$. anatoliae is unusually high for fish species (McCune and Lovejoy, 1998), and in general, for vertebrate groups (Avise and Walker, 1998). However, our results are in agreement with the works of Villwock (1958, 1964, 1966). Reproductive groups identified by Villwock (1964) form monophyletic groups in our analyses. Furthermore, there appears to be a correlation between the degree of genetic divergence and the degree of reproductive isolation; clades showing the greatest degree of pairwise genetic divergence also show the greatest degree of reproductive isolation and vice versa (Table 2). The distinct clades of $A$. anatoliae may therefore represent real species; however, this hypothesis will require additional testing.

\subsection{Morphological evolution of central Anatolian Apha- nius species}

In contrast to molecular genetic variation, little morphological and color variation is present in central Anatolian Aphanius populations (Fig. 2). There are few diagnostic differences among species. The dark crossbars typical of central Anatolian species vary in thickness and number within and among the three Anatolian 
Table 2

Species and their populations as defined by Villwock (1964) and the present work

\begin{tabular}{|c|c|c|c|c|c|c|}
\hline Species & Villwock (1964) & Present work & & & & \\
\hline Aphanius danfordii (I) & Kızilırmak group & Kızilırmak drainage clade & & & & \\
\hline Aphanius sp. aff danfordii (II) & Lake Çavuşçu population & Haymana basin clade & & & & \\
\hline Aphanius anatoliae (III) & Central Anatolian group & Tuzgölü basin clade & & & & \\
\hline Aphanius anatoliae (IV) & $\begin{array}{l}\text { Southwestern Anatolian } \\
\text { group }\end{array}$ & Lakes District clade & & & & \\
\hline Aphanius anatoliae (V) & - & Büyük-Menderez clade & & & & \\
\hline \multirow[t]{2}{*}{ Aphanius anatoliae (VI) } & - & Southwestern clade & & & & \\
\hline & I & II & III & IV & V & VI \\
\hline I & - & Complete & Complete & Complete & $?$ & $?$ \\
\hline II & 0.09211 & - & Complete & Complete & $?$ & $?$ \\
\hline III & 0.08358 & 0.07769 & - & Partial & $?$ & $?$ \\
\hline IV & 0.08917 & 0.08002 & 0.07445 & - & $?$ & $?$ \\
\hline V & 0.08829 & 0.08414 & 0.07534 & 0.07649 & - & $?$ \\
\hline VI & 0.08711 & 0.08002 & 0.07975 & 0.07649 & 0.07885 & - \\
\hline
\end{tabular}

The degree of genetic divergence between populations and degree of reproductive isolation as defined by Villwock (1964). Upper diagonal shows levels of reproductive isolation according to Villwock (1964) and lower diagonal shows uncorrected " $p$ " pairwise genetic differentiation.

species, however. Aphanius sp. aff. danfordii possesses within and among populations relatively uniform, thin cross-bars that range in number from 13 to 19. Aphanius danfordii has thicker cross-bars that vary in thickness within and among populations and also range in number from 9 to 13 . The most variable species is $A$. anatoliae, which differs within and among populations in cross-bar thickness and number, ranging from 5 to 14 cross-bars; however, no diagnostic differences appear to exist among the four major clades. Aphanius anatoliae also shows morphological differentiation in four populations. While its typical habitat consists of creeks, springs, or small wetlands in isolated inter-montane basins, numerous populations of the Lakes District region (Fig. 1, Region IV) also inhabit large lakes. In the bitter Lakes Salda, Burdur, Gölçük, and Aci, which have high magnesium salt content, A. anatoliae is the only native fish present; in these lakes, $A$. anatoliae has evolved distinct limnetic phenotypes. The limnetic populations do not form a monophyletic group, however, and are deeply nested within the nominal subspecies of A. anatoliae (Figs. 2-4); traditionally, they have been regarded as distinct species or subspecies (Grimm, 1980). In other large lakes that contain native fishes besides $A$. anatoliae, $A$. anatoliae are found only in sheltered reedy shore habitats and possess non-limnetic phenotypes, similar to those observed in fish from stream and spring habitats, and to those of $A$. danfordii and $A$. sp. aff. danfordii.

\subsection{Geological evolution of central Anatolia}

The central Anatolian region is an early-middle Eocene ( $\sim 50$ MYA) conglomerate. It consists of the Kirşehir block, the Menderez-Taurus block, and the Sakarya continent, with the Tuzgölü and Haymana basins trapped between them (Görür et al., 1984; Sengör and Yilmaz, 1981). The Kirşehir block became isolated from the Tuzgölü basin by a volcanic chain that became active during the Oligocene ( 30 MYA) (Görür et al., 1984); however, this area has undergone repeated bouts of erosion and volcanism (Sengör and Yilmaz, 1981) and appears to have allowed movement of Aphanius between these two areas well after the onset of volcanism. However, extensive uplifting at suture zones separating various elements, and thus isolation of the elements, did not occur until the closing of the Madden complex by 12 MYA (Aktas and Robertson, 1984). Additionally, the Menderez-Taurus block has undergone significant folding and uplift 5-10 MYA due to the acceleration of northward movement of the Arabian plate and the Alanya massif (Quennell, 1984; Waldron, 1984). This northward movement resulted in increased isolation of the Menderez-Taurus block from other Anatolian regions and the isolation of faunal elements within the southwestern section of the block. The Tuzgölü basin has been flooded to various degrees, the last extensive flooding occurred during the Pleistocene (Roberts et al., 1979). It has acted predominantly as the catchment area of the fauna of the Menderez-Taurus block. The Haymana basin has acted separately of the Tuzgölü basin and has remained a catchment of the Sakarya continent throughout the geological evolution of the region (Görür et al., 1984). A schematic representation of the conglomeration of Anatolia at 10 million year intervals is shown in Fig. 5.

In summary, central Anatolia is composed of five main geologic units; the Kirşehir and the MenderezTaurus blocks, the Sakarya continent, and the Tuzgölü and Haymana basins trapped between them. These five areas have acted historically as separate geologic and biogeographic units. One of the areas, the Menderez- 


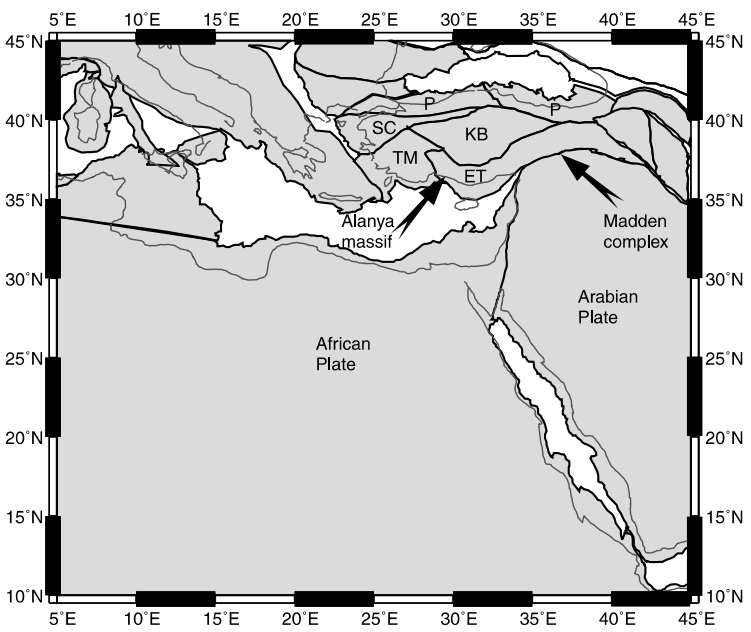

5.0 Ma Reconstruction

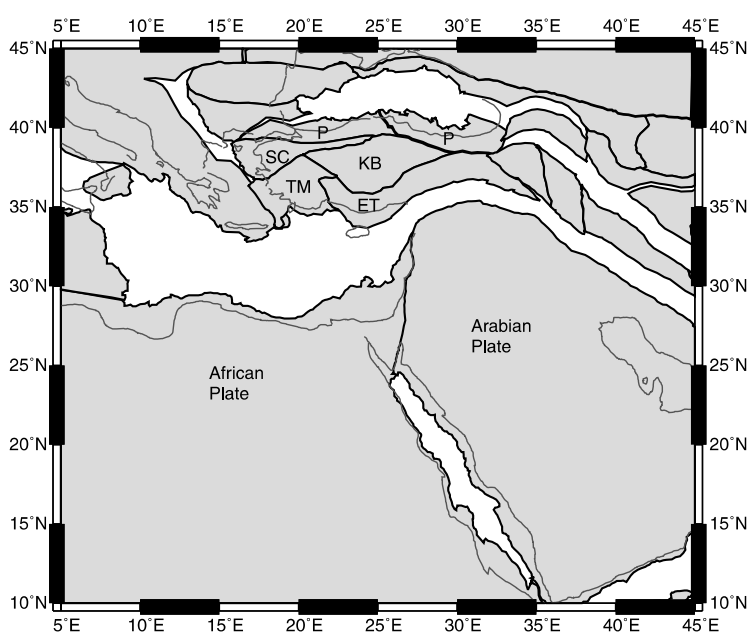

25.0 Ma Reconstruction

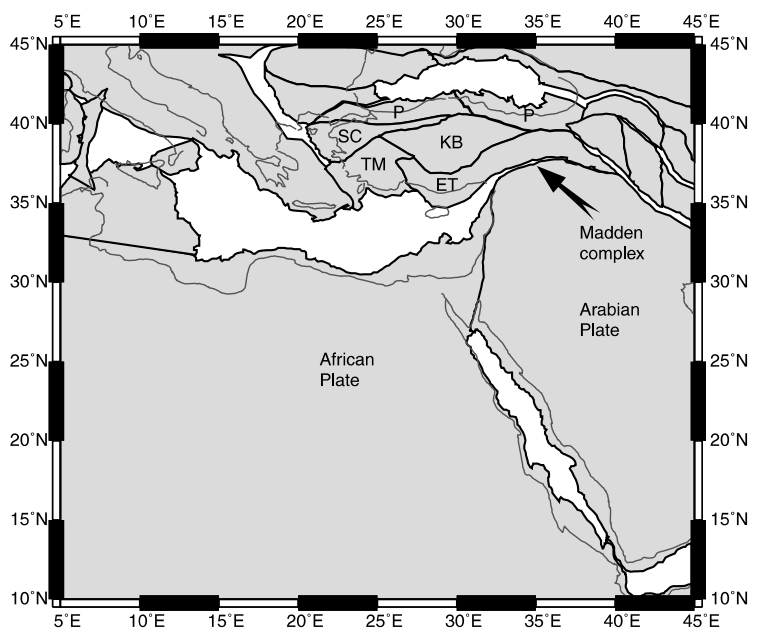

10.0 Ma Reconstruction

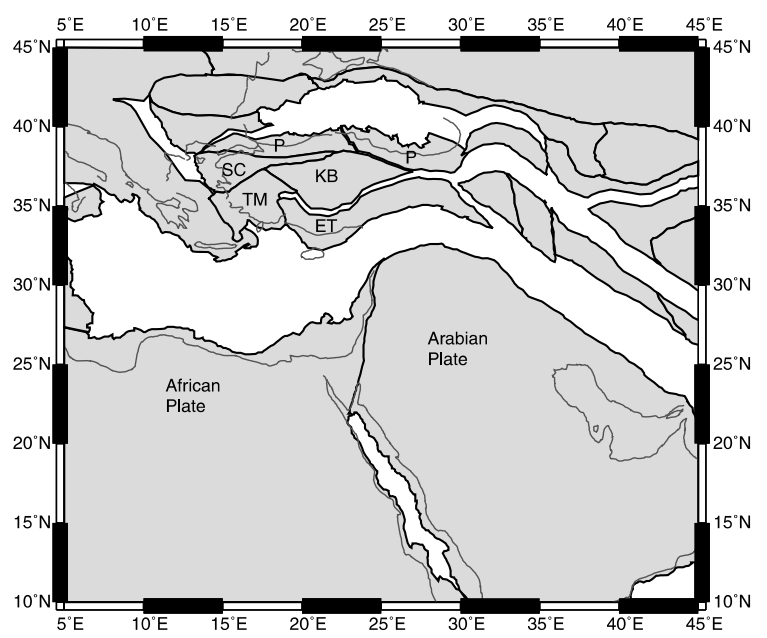

35.0 Ma Reconstruction

Fig. 5. A simplified account of the geological history of the conglomeration of Anatolia based on maps of the website of the Ocean Drilling Stratigraphic Network (Hay et al., 1999). Conglomeration of all Anatolian elements occurred by 30 MYA; however, extensive uplifting at suture zones separating various elements, and thus isolation of the elements, did not occur until the closing of the Madden complex by 12 MYA. Additional uplifting of the southwestern section of the Taurus-Menderez block occurred 10-5 MYA as a result of indentation of the Alanya massif into the Taurus-Menderez block. Thin gray lines represent current coast lines. Geological blocks are shared in gray and ancient coastlines lie between them. Codes in figures are: SC-Sakarya continent, TM-Taurus-Menderez block, KB-Kirşehir block, ET-East Taurus block, P-The Pondites and the African and Arabian plates.

Taurus block, has undergone rapid and significant folding in its southwestern section, causing the creation of countless isolated valleys, which have also acted as biogeographically separate, however, to each other related units. Another area, the Tuzgölü basin, was not completely emerged, and thus, could not have contained suitable habitat until the final recession of a palaeo-lake Tuz during the Pleistocene (Roberts et al., 1979).

\subsection{Historical biogeography of central Anatolia}

The molecular and hybridization data for central Anatolian Aphanius are concordant with the geological history of central Anatolia. We observe monophyletic groups inhabiting the Kirşehir block ( $A$. danfordii), the Haymana basin, an extension of the Sakarya continent ( $A$. sp. aff. danfordii), with the Tuzgölü basin ( $A$. anatoliae), and the Menderez-Taurus block (A. anatoliae). Based on our calculations, we estimate 11.5-14.1 million year divergence among the main Aphanius clades inhabiting the Kirşehir block, the Menderez-Taurus blocked and the Haymana basin (Hrbek and Meyer, 2002). Within the Menderez-Taurus block, we also see an unresolved separation of $A$. anatoliae into the BüyükMenderez River drainage, the Lakes District, and southwestern block clades, which show similar levels of among-clade sequence divergence. The Büyük-Menderez River drainage clade inhabits the geological suture 
of the Menderez-Taurus block and the Sakarya continent. The Lakes District clade inhabits the northern section of the Menderez-Taurus block, while the southwestern clade inhabits the southern section, the Dağları mountains of the Menderez-Taurus block. The uplift and folding of the Menderez-Taurus block 10-5 MYA as a result of the collision with the Alanya massif (Quennell, 1984; Waldron, 1984) is concordant with our 7.1 million year estimate of maximum among population within clade divergence.

The Tuzgölü basin clade of $A$. anatoliae inhabits a large area, however, among-population sequence divergence is low, and is likely correlated with a relatively recent colonization of the basin. Nested within the Tuzgölü clade are $A$. anatoliae populations from Lake Beyşehir. Currently, an irrigation canal drains Lake Beyşehir into the plain south of the city Konya. Based on historical records and maps, the construction of the $68 \mathrm{~km}$ long irrigation canal was started in 1914 and completed within two years. The canal itself is a channelized and regulated River Çarşamba, which acted as a natural drainage of Lake Beyşehir, emptying into a large wetland in the Tuzgölü basin; the wetland was historically located south of Konya and has been drained for agricultural purposes in the earlier part of this century. Historical and molecular data therefore support the hypothesis that Lake Beyşehir has been the source population of $A$. anatoliae that colonized the Tuzgölü plain after its emergence near the end of the Pleistocene (Roberts et al., 1979) and that downstream directed gene flow from Lake Beyşehir may continue. Low genetic differentiation among populations within the Büyük-Menderez and the Kızllırmak drainages suggests that gene flow can play a significant role in shaping the population structuring of Aphanius; however, the ecological opportunity must exist.

Aphanius killifishes are likely not unique in showing this kind of biogeographic pattern. The co-distributed fish species of the genus Pseudophoxinus (Cyprinidae) would be ideal candidates for testing the generality of the biogeographical scenario, as may salamandrid salamanders (Veith et al., 1998; Weisrock et al., 2001) and possibly melanopsid snails (Glaubrecht, 1993). Recently, Weisrock et al. (2001) have investigated the phylogenetic relationships of populations of the salamander Mertensiella luschani from the southwestern section of the Menderez-Taurus block, region VI of our study. This region, together with the Lakes District region, experienced significant folding and uplift 510 MYA (Waldron, 1984). Weisrock et al. (2001) came to a qualitatively similar conclusion as we do regarding the biogeography of this area. M. luschani populations were deeply divergent and were estimated to have differentiated 5.9-7.9 MYA (7.6-10.1\% pairwise sequence divergence) a range of dates concordant with those calculated for $A$. anatoliae populations from the Lakes
District area. Thus, it appears that the geological history of Anatolia has had a profound impact on the general biogeography of the region; however, additional studies necessary to investigate the generality of this pattern are warranted.

\section{Acknowledgments}

We thank Fevzi Bardakçi, Kees Valkenburg, Bas Vlijm, and Ingo Wildekamp who were excellent and highly knowledgeable field companions. Jaime GarciaMoreno read an earlier version of the paper. Support for this research was provided in part by the National Science Foundation (Postdoctoral Grant INT-0002213 to $\mathrm{TH})$, the Belgian grant for Inter-university Poles of Attraction Program (to RW), and by grants from the Deutsche Forschungsgemeinschaft and the University of Konstanz (to AM).

\section{References}

Aktas, G., Robertson, A.H.F., 1984. The Maden complex, SE Turkey: evolution of a Neotethyan active margin. In: Dixon, J.E., Robertson, A.H.F. (Eds.), The geological evolution of the Eastern Mediterranean. Geological Society Special Publication No. 17. Blackwell Scientific, Oxford, pp. 375-402.

Avise, J.C., Walker, D., 1998. Pleistocene phylogeographic effects on avian populations and the speciation process. Proc. Roy. Soc. London B 265, 457-463.

Bremer, K., 1994. Branch support and tree stability. Cladistics 10, 295 304.

Felsenstein, J., 1985a. Confidence limits on phylogenies: an approach using the bootstrap. Evolution 39, 783-791.

Felsenstein, J., 1985b. Confidence limits on phylogenies with a molecular clock. Syst. Zool. 34, 152-161.

Futuyma, D.J., Mayer, G.C., 1980. Non-allopatric speciation in animals. Syst. Zool. 29, 254-271.

Glaubrecht, M., 1993. Mapping the diversity: geographical distribution of the freshwater snail Melanopsis (Gastropoda: ? Cerithioidea: Melnopsidae) with the focus on its systematics in the Mediterranean basin. Mitt. Hamb. Zool. Mus. Inst. 90, 41-97.

Görür, N., Oktay, F.Y., Seymen, I., Sengör, A.M.C., 1984. Palaeotectonic evolution of the Tuzgölü basin complex, Central Turkey: sedimentary record of a Neo-Tethyan closure. In: Dixon, J.E., Robertson, A.H.F. (Eds.), The Geological Evolution of the Eastern Mediterranean. Geological Society Special Publication No. 17 Blackwell Scientific, Oxford, pp. 467-482.

Graybeal, A., 1998. Is it better to add taxa or characters to a difficult phylogenetic problem? Syst. Biol. 47, 9-17.

Grimm, H., 1980. Investigations on the problem of scale reduction and sulphate tolerance of West-Anatolian Cyprinodonts (Pisces). Int. Rev. Gesammt. Hydrobiol. 65, 280-517.

Hall, T., 1999. BioEdit: a user-friendly biological sequence alignment editor and analysis program for Windows 95/98/NT. Nucl. Acids Symp. Ser. 41, 95-98.

Hasegawa, M., Kishino, H., Yano, T.A., 1985. Dating of the humanape splitting by a molecular clock of mitochondrial DNA. J. Mol. Evol. 22, 160-174.

Hay, W.W., DeConto, R., Wold, C.N., et al., 1999. Alternative global cretaceous paleogeography. In: Barrera, E., Johnson, C. (Eds.), 
The Evolution of Cretaceous Ocean/Climate Systems. Geological Society of America Special Paper 332, pp. 1-47.

Hillis, D.M., 1996. Inferring complex phylogenies. Nature 383, 130-131.

Hillis, D.M., Bull, J.J., 1993. An empirical test of bootstrapping as a method for assessing confidence in phylogenetic analysis. Syst. Biol. 42, 182-192.

Hrbek, T., Meyer, A., 2002. Closing of the Tethys Sea and the phylogeny of Eurasian killifishes (Cyprinodontiformes: Cyprinodontidae). J. Evol. Biol. (in press).

Jackman, T.R., Larson, A., de Queiroz, K., Losos, J.B., 1999. Phylogenetic relationships and tempo of early diversification in Anolis lizards. Syst. Biol. 48, 254-285.

Kishino, H., Hasegawa, M., 1989. Evaluation of the maximum likelihood estimate of the evolutionary tree topologies from DNA sequence data, and the branching order in Hominoidea. J. Mol. Evol. 29, 170-179.

Kosswig, C., 1953. Über die Verwandschaftsbeziehungen anatolischer Zahnkarpfen. Hidrobiologi, Istanbul Univ. Fen Fac. Ser. B 1, 186198.

Kosswig, C., 1956. Über Makro-und Mikropopulationen des Zahnkarpfens Anatolichthys. Zool. Anz. 156, 75-90.

Kumazawa, Y., Nishida, M., 1993. Sequence evolution of mitochondrial tRNA genes and deep-branch animal phylogenetics. J. Mol. Evol. 37, 380-398.

Mayr, E., 1942. Systematics and the Origin of Species. Columbia University Press, New York, NY.

McCune, A.R., Lovejoy, N.R., 1998. The relative rate of sympatric and allopatric speciation in fishes: tests using DNA sequence divergence between sister species and among clades. In: Howard, D.J., Berlocher, S.H. (Eds.), Endless Forms: Species and Speciation. Oxford University Press, Oxford.

Ortí, G., Meyer, A., 1997. The radiation of characiform fishes and the limits of resolution of mitochondrial ribosomal DNA sequences. Syst. Biol. 46, 75-100.

Ortí, G., Petry, P., Porto, J.I.R., Jégu, M., Meyer, A., 1996. Patterns of nucleotide changes in mitochondrial ribosomal RNA genes and the phylogeny of piranhas. J. Mol. Evol. 42, 169-182.

Philippe, H., Chenuil, A., Adoutte, A., 1994. Can the Cambrian explosion be inferred through molecular phylogeny? Development 1994 (Suppl.), 15-25.

Quennell, A.M., 1984. The western Arabia rift system. In: Dixon, J.E., Robertson, A.H.F. (Eds.), The Geological Evolution of the Eastern Mediterranean. Geological Society Special Publication No. 17. Blackwell Scientific, Oxford, pp. 775-778.

Rambaut, A., Grassly, N.C., 1997. Seq-Gen: an application for the Monte Carlo simulation of DNA sequence evolution along phylogenetic trees. Comp. Appl. Biosci. 13, 235-238.

Roberts, N., Erol, O., de Meester, T., Uerpman, H.F., 1979. Radiocarbon chronology of the late Pleistocene Konya lake, Turkey. Nature 281, 662-664.

Sengör, A.M.C., Altiner, D., Cin, A., Ustaomer, T., Hsü, K.J., 1988. Origin and assembly of the Tethyside erogenic collage at the expense of Gondwana Land. In: Audley-Charles, M.G., Hallam, A. (Eds.), Gondwana and the Tethys. Geological Society Special Publication No. 37. Oxford University Press, New York, NY.

Sengör, A.M.C., Yilmaz, Y., 1981. Tethyan evolution of Turkey: a plate tectonic approach. Tectonophysics 75, 181-241.

Swofford, D.L., 2001. PAUP*. Phylogenetic analysis using parsimony (* and other methods), Beta version 4.0b6. Sinauer Associates, Sunderland, MA.

Templeton, A., 1983. Phylogenetic inference from restriction endonuclease cleavage site maps with particular reference to the evolution of humans and the apes. Evolution 37, 221-244.

Van de Peer, Y., De Wachter, R., 1997. Construction of evolutionary distance trees with TREECON for Windows: accounting for variation in nucleotide substitution rate among sites. Comp. Appl. Biosci. 13, 227-230.

Van de Peer, Y., Van der Auwera, G., De Wachter, R., 1996. The evolution of stramenopiles and alveolates as derived by "substitution rate calibration" of small ribosomal subunit RNA. J. Mol. Evol. 42, 201-210.

Veith, M., Steinfartz, S., Zardoya, R., Seitz, A., Meyer, A., 1998. A molecular phylogeny of 'true' salamanders (family Salamandridae) and the evolution of terrestriality of reproductive modes. J. Zool. Syst. Evol. Res. 36, 7-16.

Villwock, W., 1958. Weitere genetische Untersuchungen zur Frage der Verwandtschaftsbeziehungen anatolischer Zahnkarpfen. Mitt. Hamb. Zool. Mus. Inst. 56, 81-153.

Villwock, W., 1964. Genetische Untersuchungen an altweltlichen Zahnkarpfen der Tribus Aphaniini (Pisces: Cyprinodontidae) nach Gesichtpunkten der neuen Systematik. J. Zool. Syst. Evol. Res. 2, 267-382.

Villwock, W., 1966. Isolationsmechanismen und Artenbildung bei Fischen, unter besonderer Berücksichtigung geographischer Isolationsfaktoren. Zool. Anz. 177, 84-104.

Waldron, J.W.F., 1984. Structural history of the Antalya complex in the 'Isparta angle,' southwest Turkey. In: Dixon, J.E., Robertson, A.H.F. (Eds.), The Geological Evolution of the Eastern Mediterranean. Geological Society Special Publication No. 17. Blackwell Scientific, Oxford, pp. 273-286.

Weisrock, D.W., Macey, J.R., Ugurtas, I.H., Larson, A., Papenfuss, T.J., 2001. Molecular phylogenetics and historical biogeography among salamandrids of the "true" salamander clade: rapid branching of numerous highly divergent lineages in Mertensiella luschani associated with the rise of Anatolia. Mol. Phyl. Evol. 18, 434-448.

Wildekamp, R.H., Küçük, F., Ünlüsayin, M., Neer, W.V., 1999. Species and subspecies of the genus Aphanius Nardo 1897 (Pisces: Cyprinodontiformes) in Turkey. Turk. J. Zool. 23, 2344.

Zhang, D.-X., Hewitt, G.M., 1996. Nuclear integrations: challenges for mitochondrial DNA markers. Trends Ecol. Evol. 11, 247251. 